\title{
Studies with Rhinoviruses in Volunteers: Production of Illness, Effect of Naturally Acquired Antibody, and Demonstration of a Protective Effect Not Associated with Serum Antibody*
}

\author{
Thomas R. Cate, Robert B. Couch, and Karl M. Johnson $\dagger$ \\ (From the U.S. Public Health Service, National Institute of Allergy and Infectious Diseases, \\ Laboratory of Clinical Investigations and Laboratory of Infectious Diseases, \\ Bethesda, Md.)
}

The term "rhinovirus" (1-3) is now used to designate a group of immunologically distinct respiratory viruses, possessing many properties of enteroviruses but differing by lability in acid media (4-6) and almost exclusive multiplication in the nasopharynx. The first agents isolated that fit this description were the $\mathrm{JH}$ and 2060 strains of ECHO 28 isolated by Price (7) and Pelon, Mogabgab, Phillips, and Pierce (8) in 1956 and classified by Pelon (9). Modifications in tissue culture technique for isolating these and similar agents, i.e., incubation on a rotating drum and reduction in $\mathrm{pH}$ to 7.0 to 7.3 , were introduced by Pelon and Mogabgab (10) and extended by Tyrrell and associates (4) and Tyrrell and Parsons (5) to include an incubation temperature of $33^{\circ}$ $\mathrm{C}$ and use of human tissues. Subsequently, many rhinoviruses, reported under a variety of names, have been isolated in association with mild respiratory illnesses (11-16). Some of the strains grow only in tissues of human origin ( $\mathrm{H}$ strains) and some as well in monkey kidney tissue culture ( $M$ strains) $(3,5)$. It has been estimated that rhinoviruses account for 35 to $40 \%$ of the common colds in adults (17).

Tyrrell, Bynoe, and co-workers $(4,18-20)$ and Jackson, Dowling, and Mogabgab (21), who have administered rhinoviruses to volunteers, have demonstrated that the viruses can infect and produce common colds and that protection is associated with the presence of specific neutralizing antibody in the serum. After the isolation of other strains of rhinovirus, NIH 353, 1734, and 11757, by

* Submitted for publication June 24, 1963; accepted September 26, 1963.

$\dagger$ Present address: Middle America Research Unit, Balboa Heights, Canal Zone.
Johnson and associates (16), our studies were undertaken in volunteers to determine the viruses' properties as infectious agents of man. The results were in agreement with the findings of previous observers but in addition revealed the existence of a substantial resistance to homologous rechallenge that is distinct from the more limited protective effect of naturally acquired antibody.

\section{Materials and Methods}

Volunteers and clinical procedures. Subjects were fifty-seven adult male volunteers from several federal correctional institutions who had no medical contraindications to the inoculations. Twenty-eight were inoculated at the Clinical Center, National Institutes of Health, and the remainder were inoculated at the Federal Prison Camp, Greenville, South Carolina. The inoculum used, the dose, the location, the date, and the identifying numbers of participants are shown in Table I.

At the Clinical Center, men were isolated, three per room, for 4 days before and for 10 days after inoculation. The volunteers were examined daily before and after inoculation by physicians who did not know which of several viruses (including agents other than rhinoviruses) had been given.

At Greenville, S. C., the men were assigned to two large, adjoining rooms without isolation; they continued their usual work assignments around the camp. Physicians who made daily examinations for 5 days were aware of which agent had been administered. The Greenville, S. C., studies were made in August and September, 1962. Respiratory illness was infrequent in the camp in the early part of the period, but a mild outbreak of common cold occurred in late September. Some extraneous rhinoviruses were isolated at this time and on two other occasions. These are described under Results.

Inocula. The three virus strains used, NIH 353, NIH 1734, and NIH 11757, were isolated from throat swab specimens from two Marine recruits and a 2-year-old female (16). Johnson and Rosen have described the characteristics of these three strains, which grow only in tissue of human origin (22). All were isolated in a 
TABLE I

Schedule of inoculation of volunteers with rhinoviruses

\begin{tabular}{lclcc}
\hline \hline Inoculum & Dose* & Location & $\begin{array}{c}\text { Date of } \\
\text { inoculation }\end{array}$ & $\begin{array}{c}\text { Volunteer identi- } \\
\text { fication no. }\end{array}$ \\
\hline NIH 353 & $10^{5.2}$ & Clinical Center & $11 / 28 / 61$ & $1-3$ \\
& $10^{4.8}$ & Clinical Center & $12 / 26 / 61$ & $10-12$ \\
& & & & $1 \mathrm{R}, 2 \mathrm{R}, 3 \mathrm{R} \dagger$ \\
NIH 11757 & $10^{5.0}$ & Clinical Center & $11 / 28 / 61$ & $4-6$ \\
& $10^{5.8}$ & Clinical Center & $12 / 26 / 61$ & $13,14,4 \mathrm{R}, 5 \mathrm{R}, 6 \mathrm{R}$ \\
NIH 1734 & $10^{3.5}$ & Clinical Center & $11 / 28 / 61$ & $7-9$ \\
& $10^{5.5}$ & Clinical center & $12 / 26 / 61$ & $15-17,7 \mathrm{R}, 9 \mathrm{R}$ \\
& $10^{2.8}$ & Clinical Center & $3 / 12 / 62$ & $18-28$ \\
& $10^{2.8}$ & Greenville, S. C. & $8 / 31 / 62$ & $29-41$ \\
& $10^{2.8}$ & Greenville, S. C. & $9 / 21 / 62$ & $42-57$ \\
\hline
\end{tabular}

* Contained in $2 \mathrm{ml}$ given by nasopharyngeal spray and instillation. Based on titrations at time of inoculations and expressed as TCID 6.
$+R$ indicates volunteers who received homologous rechallenge.

human embryonic fibroblast cell culture (WI-26) (23), and the harvest of a second WI-26 passage of each strain was pooled for a volunteer inoculum. Each volunteer inoculum was centrifuged for 20 minutes at $2,000 \mathrm{rpm}$, filtered through an $800-\mathrm{m} \mu$ gradocol membrane, and stored in 2-ml amounts in heat-sealed ampules at $-60^{\circ}$ C. Inocula were safety tested in a manner previously described (24).

Volunteers were given $1 \mathrm{ml}$ of virus suspension intranasally with a coarse hand spray and another $1 \mathrm{ml}$ by intranasal instillation with a pipette.

Nasal secretions. The daily amount of nasal discharge in grams was determined by collecting from each subject used paper handkerchiefs in plastic bags and weighing these tissues. From this value was subtracted the weight of a like number of unused tissues. To correct for any pre-existing rhinorrhea, the weight of secretion in the 48 hours before inoculation was subtracted from that of the 48 hours after inoculation.

Collection of specimens. Swabs from subjects were agitated in vials with $2 \mathrm{ml}$ of veal infusion broth containing $0.5 \%$ bovine albumin and antibiotics. The swabs were then discarded. Nasopharyngeal washings were performed by instilling $5 \mathrm{ml}$ of the above medium into each nostril with the subject's head tilted back and then, with his head tilted forward, collecting the fluid in disposable paper cups. After being mixed, the wash specimen was dispensed in vials. Pharyngeal and nasal swabbings were always performed before nasopharyngeal washes. The isolation results reported are derived from the nasopharyngeal wash specimen alone unless otherwise specified. Essentially identical isolation results were obtained whether specimens were cultured for virus when fresh or when recultured after storage at $-20^{\circ} \mathrm{C}$ for 1 to 10 weeks. At Greenville, S. C., specimens were stored at $-4^{\circ} \mathrm{C}$ for several days before shipment to the Clinical Center.

Stool specimens were collected and stored at $-20^{\circ} \mathrm{C}$. They were subsequently thawed and homogenized as a 10 to $20 \%$ solution in either saline or Hanks balanced salt solution with antibiotics. The homogenate was then centrifuged at 3,000 to $8,000 \mathrm{rpm}$ for 30 minutes and the supernatant fluid stored at $-20^{\circ} \mathrm{C}$ until tested.

To test for the presence of virus, $0.4 \mathrm{ml}$ of each specimen was inoculated into one WI-26 tube. Maintenance medium consisted of equal parts of medium no. 199 and Eagle's medium no. 2 containing $2 \%$ inactivated $\left(56^{\circ} \mathrm{C}\right.$, 30 minutes) calf serum, $0.4 \%$ saturated solution of sodium bicarbonate, and supplemental antibiotics. The cultures were incubated at $34^{\circ} \mathrm{C}$ on a rotating drum and observed for cytopathic effect (CPE) for 13 to 14 days. Positive cultures were harvested when the CPE involved all of the culture. Positive cultures in which CPE failed to progress were occasionally seen and were verified on subpassage. Identity of the first and last isolates from each subject was established in WI-26 tissue culture by neutralization of 32 or more $\operatorname{TCID}_{50}{ }^{1}$ with not more than 20 antibody units of specific hyperimmune guinea pig serum.

Antibody determinations. Neutralization tests were performed in WI-26 with a test dose of virus calculated to give 3.2 to $10 \mathrm{TCID}_{50}$. Equal volumes of virus and fourfold dilutions of heat inactivated serum $\left(56^{\circ} \mathrm{C}, 30\right.$ minutes) were incubated for 1 hour at room temperature, and then $0.2 \mathrm{ml}$ of this mixture was inoculated into each of two culture tubes. Simultaneous tenfold dilutions of the test dose of virus were inoculated into each of four culture tubes. Five or more foci of CPE in a culture tube were required to consider that tube positive. When the presence of 3.2 (not more than 16) $\mathrm{TCID}_{50}$ was first noted in the simultaneous virus titration, a definitive reading of the test was made. The antibody titer, calculated according to the method of Reed and Muench (25), was defined as that initial dilution of serum inhibiting this dose of virus. The test has given consistently reproducible results.

\section{Results}

Illness. Common cold syndromes occurred in 38 of 56 volunteers. Volunteer 21 had a preinoculation respiratory illness and is not included in subsequent parts of this report except in Table VI. Forty-five of the 56 volunteers were inoculated with strain 1734 (including 7 men from whom extraneous rhinoviruses were isolated); of these, 29 became ill. Six received NIH 353; four became ill. Five received NIH 11757 and all became ill. Despite strain, inoculum size, antibody status, and geographic and seasonal differences, the characteristics of the individual illnesses were very much alike, and illness among groups was indistinguishable by clinical observation. For that reason the composite description of illness in

$1 \mathrm{TCID}_{50}=$ the dose of virus that will infect $50 \%$ of tissue cultures, as calculated according to Reed and Muench (25). 
TABLE II

Clinical response in 38 volunteers with illness after intranasal challenge with rhinoviruses

\begin{tabular}{|c|c|c|c|c|c|c|}
\hline & & & \multicolumn{2}{|l|}{ Symptom } & \multicolumn{2}{|l|}{ Sign } \\
\hline & Constitutional & . & $\begin{array}{l}\text { Headache } \\
\text { Malaise } \\
\text { Chilliness, sweats } \\
\text { Myalgia }\end{array}$ & $\begin{array}{l}66 \% \\
50 \% \\
39 \% \\
24 \%\end{array}$ & $\begin{array}{l}\text { Temperature, elevation, } \\
\geq 37.5^{\circ} \mathrm{C} \text {, oral }\end{array}$ & $16 \%$ \\
\hline & \multirow{2}{*}{\multicolumn{2}{|c|}{ Upper respiratory }} & $\begin{array}{l}\text { Nasal discharge } \\
\text { Nasal obstruction } \\
\text { Sneezing }\end{array}$ & $\begin{array}{r}100 \% \\
92 \% \\
76 \%\end{array}$ & $\begin{array}{l}\text { Nasal discharge } \\
\text { Nasal obstruction } \\
\text { Inflamed nasal mucosa }\end{array}$ & $\begin{array}{r}100 \% \\
89 \% \\
97 \%\end{array}$ \\
\hline & & & $\begin{array}{l}\text { Throat irritation } \\
\text { Eye discomfort } \\
\text { Earache }\end{array}$ & $\begin{array}{r}53 \% \\
18 \% \\
3 \%\end{array}$ & $\begin{array}{l}\text { Pharyngeal injection } \\
\text { Mild cervical adenopathy } \\
\text { Injected palpebral conjuctiva } \\
\text { Dull tympanic membranes }\end{array}$ & $\begin{array}{r}24 \% \\
26 \% \\
16 \% \\
8 \%\end{array}$ \\
\hline & Pulmonary & & $\begin{array}{l}\text { Cough } \\
\text { Chest discomfort }\end{array}$ & $\begin{array}{l}66 \% \\
21 \%\end{array}$ & Rales & $0 \%$ \\
\hline$\because$ & Gastrointestinal & & $\begin{array}{l}\text { Anorexia } \\
\text { Vomiting } \\
\text { Loose bowels }\end{array}$ & $\begin{array}{r}21 \% \\
5 \% \\
5 \%\end{array}$ & - & \\
\hline
\end{tabular}

Table II is based on all of the 38 rhinovirus illnesses that were observed.

Characteristically, nasal symptoms began on the day after inoculation. Gradually increasing complaints followed, with maximal illness on the second or third day. During the acute phase of illness, a typical case was characterized by nasal discharge and obstruction, sneezing, coughing, slightly sore throat, headache, and malaise. Temperature elevations occurred in 6 volunteers during the acute illness, with maximal oral temperatures ranging from 37.6 to $38.5^{\circ} \mathrm{C}$. In addition, slight elevations over base-line temperatures occurred in the majority of volunteers 8 to 12 hours after inoculation. One other volunteer had a single oral temperature of $37.6^{\circ} \mathrm{C}$ on the fifth day after inoculation in association with persistent rhinitis and possible subacute sinusitis. Generally the volunteers were asymptomatic by the fifth day after inoculation except for a few with nasal discharge persisting for 2 to 9 more days.

On the basis of this description, a classification of severity of illness was prepared as follows : $0=$

W.W.A., 38 Yr. $0^{7}$ VOLUNTEER \# 9

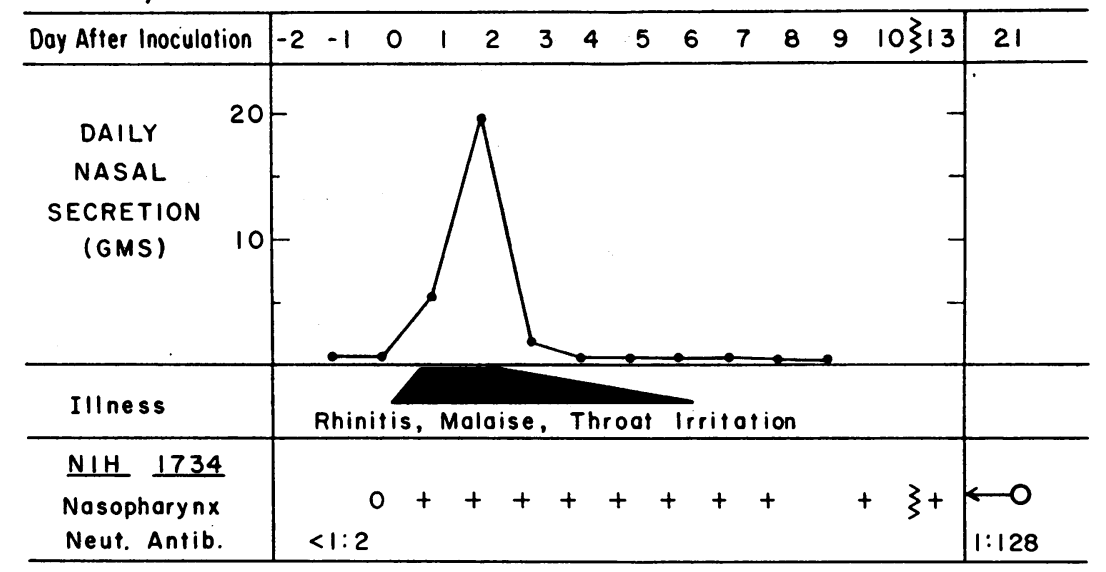

Fig. 1. Common cold with Rhinovirus NIH 1734 in a NORMal volunteer. Daily nasal secretions increased to $20 \mathrm{~g}$ on the second day after inoculation in association with a syndrome of common cold. Virus was isolated from nasopharyngeal wash specimens taken days 1 through 13 . 
no illness (but some nasal discharge may be present) $;+=$ rhinitis with nasal congestion and discharge $++=$ nasal congestion, discharge, and systemic reaction; $+++=$ nasal and systemic findings and fever $\left(\geq 37.5^{\circ} \mathrm{C}\right.$, oral $)$. This classification is used in subsequent parts of the report.

Nasal secretions. The case described in Figure 1 is representative of the concurrence of illness and the period of increased nasal secretion in men who became ill among the 27 on whom such data were available. Analyses of data on nasal secretion have been limited to the first 48 hours after inoculation, when the quantity of nasal secretion was maximal. The average weight of excess of secretions (see Methods) for the 27 men in this 2-day period was $8.5 \mathrm{~g}$, with a range from 0.0 to $85.5 \mathrm{~g}$. There was a close correlation between the amount of secretion and the severity of illness [Kendall's tau $=+.543, \mathrm{p}<.01$ (26)]. The quantity of nasal secretion did not correlate with the duration of virus shedding nor with the titer of postchallenge antibody. The number of tissues used correlated with the weight of collected secretions (Kendall's tau $=+.688, \mathrm{p}<.01$ ).

Changes in leukocyte counts and sedimentation rates. Total leukocyte and differential counts were available on 15 subjects (Volunteers 1 to 9 , 18 to 22 , and 24) in the period before challenge and on days $1,2,3$, and 7 to 10 after challenge. Thirteen of these men developed illness. The average counts for leukocytes, neutrophiles, and lymphocytes shown in Figure 2 revealed a moderate but significant increase in total leukocytes because of an increase in the absolute number of circulating neutrophiles during the acute illness. Analysis of the individual series of counts by the paired sample $t$ test (27) (Figure 2) showed that the changes in average counts were due to uniform changes in counts from each volunteer. Of interest was the slight decrease in lymphocytes during the acute illness.

Erythrocyte sedimentation rates (ESR) were determined at the same times as the leukocyte counts. Five of the men (Volunteers 2, 3, 4, 7, and 9) developed ESR elevations in the range of 27 to 50 (Westergren) by 7 to 10 days after challenge. None of the other volunteers tested had ESR elevations greater than 16 at this time.

Comparison of virus yield according to source of specimen. The proportion of specimens yield-

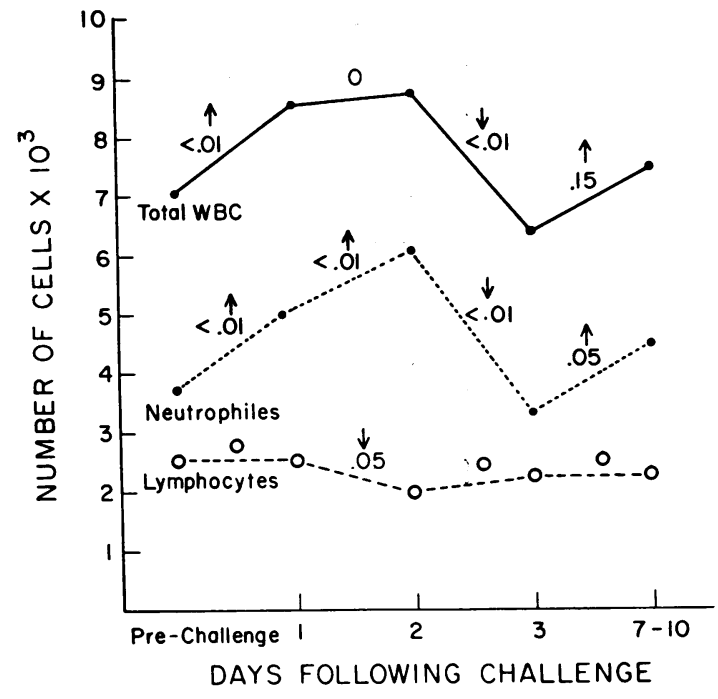

Fig. 2. Average and individual changes in leukoCYTE, NEUTROPHILE, AND LYMPHOCYTE COUNTS AFTER CHALLENGE WITH RHINOVIRUSES. The average counts are plotted, and the results of analysis of the individual series of counts by the paired sample $t$ test are indicated by arrows along with respective $\mathrm{p}$ values. $0=$ no significant change.

ing virus was determined for the nasopharyngeal wash, nasal swab, and pharyngeal swab specimens from 13 antibody-free $(<1: 2)$ volunteers during the 7-day interval following challenge. As shown in Figure 3, the nasopharyngeal wash specimen was consistently superior to the other two specimens in yielding virus. A similar pattern was noted for all three virus strains. Cumulative corresponding rates of virus recovery were as follows: nasopharyngeal wash, 62 positive of 82 specimens tested $(76 \%)$; nasal swab, $36 \%$; pharyngeal swab, $35 \%$; combination of nasal and pharyngeal swabs, $50 \%$. This superiority of the nasopharyngeal wash specimens also continued into the second and third weeks following challenge. Subsequent studies were performed using only this latter specimen for virus detection, and with one exception all of the virus recovery data reported are based on this specimen alone. Since Volunteer 16 could not tolerate nasopharyngeal washing, his isolation results are based on nasal and pharyngeal swab specimens.

Challenge of antibody-free $(<1: 2)$ volunteers. Table III shows the results of challenge of 21 antibody-free volunteers with the 3 virus strains. Seventeen illnesses were observed. No significant 


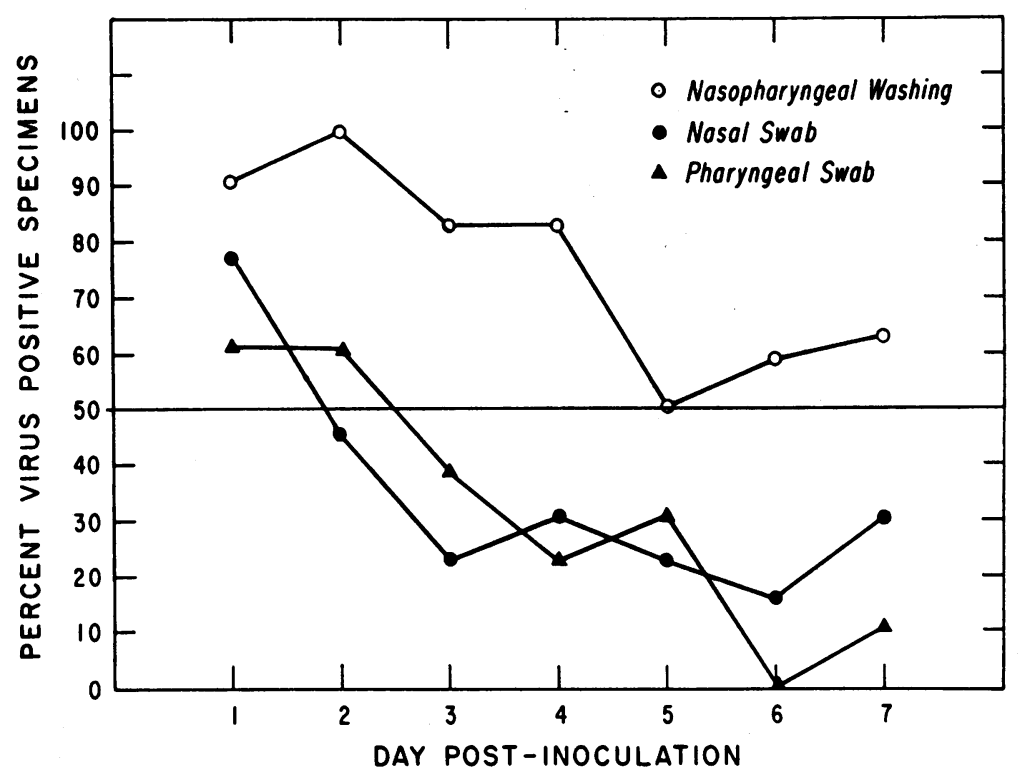

Fig. 3. Comparison of RHINovirus Yield by SOURCE OF SPECIMEN.

TABLE III

Response of antibody-free $(<1: 2)$ volunteers after intranasal challenge with rhinoviruses

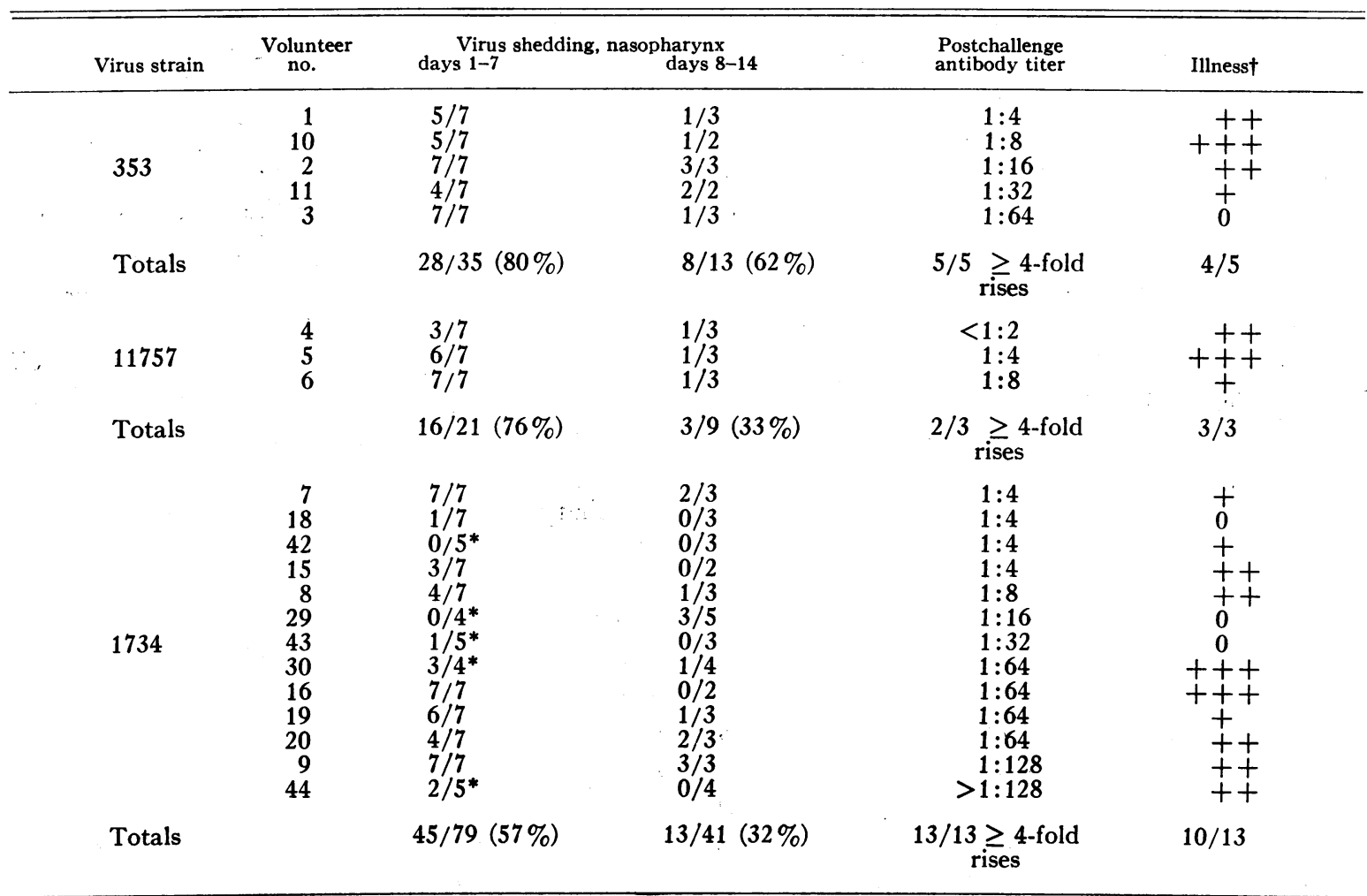

* Inoculated at the Greenville, S. C., Federal Prison Camp.

$\dagger 0=$ no illness $;+=$ rhinitis with nasal congestion and discharge $;++=$ nasal congestion, discharge, and systemic reaction; $+++=$ nasal and systemic findings and fever. 
difference could be detected among the strains in the quality or quantity of illness produced.

Virus was recovered from the nasopharynges of 20 volunteers. In general, there was profuse virus shedding from the nasopharynx during the first 2 or 3 days after challenge. Thereafter, frequency of virus recovery progressively decreased. Nine volunteers shed virus through days 11 to 14 , and 4 of 12 tested continued to shed virus through days 17 to 20 . For reasons possibly related to inadequate refrigeration, less virus was recovered from volunteers in Greenville, S. C., than from similar men at the Clinical Center. If the volunteers studied in Greenville are excluded, the average percentage of virus-positive specimens is similar for all 3 virus strains. Except for isolation of herpes simplex from one volunteer before and after inoculation, preinoculation cultures were negative, and no agents except the strain administered were recovered.

One hundred twenty rectal swab specimens and 75 stool specimens obtained from Volunteers 1 to 9 were tested for the presence of virus. Virus was recovered from one, a stool specimen obtained on day 2 from a volunteer challenged with NIH 353 , and was subsequently identified as the agent administered.

Twenty of the 21 volunteers had a fourfold or greater rise in homologous neutralizing antibody titer 3 weeks following challenge. Sera from 9 volunteers with no prechallenge antibody, 3 volunteers with each strain, were tested for neutralizing antibody at weekly intervals for 4 weeks following challenge. One developed a fourfold rise in antibody titer after 1 week, 2 after 2 weeks, and 5 after 3 weeks. One volunteer did not develop antibody in this period. None of the volunteers exhibited further increase in titer between the third and fourth weeks. Most of the antibody titers were low (12 of $21 \leq 1: 16$ ) and would have gone undetected if larger amounts of virus had been used in the test.

Paired sera from Volunteers 1 to 17 were also tested for antibody against the two of these virus strains with which the individual had not been inoculated. Antibody to one or both heterologous strains was present in the preinoculation sera of all of these volunteers. Three of the 34 tests of paired sera against heterologous virus demonstrated a bare fourfold rise in antibody titer.
These 3 instances involved all 3 viruses and in each case began from titers of $1: 16$ to $1: 32$ in the prechallenge serum.

Homologous rechallenge. Four weeks after primary challenge, 8 of the initially antibodyfree volunteers were rechallenged with the same virus strain. Eight additional volunteers were available for primary challenge at the same time to verify continued infectivity and illness-producing capacity of the inocula. The results recorded in Table IV demonstrate the nearly complete absence of virus shedding and total absence of illness in the homologously rechallenged volunteers. Nasal secretions were negligible or absent. Three of the 8 developed a further rise in antibody titer after rechallenge. In contrast were the frequent virus isolations, uniform rise in antibody titer, and 6 illnesses in the 8 volunteers who had primary challenge at this time. Two groups of physicians examined these 16 volunteers to check the accuracy of clinical diagnosis, and identical results were recorded. Both the continued potency of the inocula and a uniform potent protective effect in the homologous rechallenge group were thus demonstrated.

Challenge of volunteers having naturally acquired neutralizing antibody to NIH 1734. More extensive studies to assess the effectiveness of naturally acquired antibody were undertaken with one virus strain, NIH 1734 . Volunteers were chosen on the basis of approximations of antibody titer in sera taken 1 to 3 months before challenge. With consideration for the minimal time needed to develop antibody response, the volunteers with naturally acquired antibody must have had initial contact with 1734 virus a minimum of 6 weeks before challenge. The distribution of antibody titers in the volunteers chosen for study is a fair representation of the antibody levels found in the correctional institution population as a whole, with 20 to $40 \%$ being free of detectable antibody. All of the sera taken from volunteers immediately before challenge were tested in a single neutralization test to achieve a valid ranking according to prechallenge antibody titer. Paired sera were tested for rise in titer in one or more separate neutralization tests. Volunteers who had no detectable antibody were included in each study, and results from their challenge are tabulated in Table III. 
TABLE IV

Homologous rechallenge (4 weeks) and simultaneous primary challenge of volunteers with rhinoviruses

\begin{tabular}{|c|c|c|c|c|c|}
\hline $\begin{array}{l}\text { Volunteer } \\
\text { no. }\end{array}$ & Virus strain & $\begin{array}{l}\text { Prechallenge } \\
\text { antibody titer }\end{array}$ & $\begin{array}{l}\text { Virus shedding, } \\
\text { nasopharynx } \\
\text { days } 1-7\end{array}$ & $\begin{array}{l}\text { Postchallenge } \\
\text { antibody titer }\end{array}$ & Illness \\
\hline \multicolumn{6}{|c|}{ Homologous rechallenge } \\
\hline $\begin{array}{l}4 R \\
7 R \\
1 R \\
5 R \\
6 R \\
2 R \\
3 R \\
9 R\end{array}$ & $\begin{array}{r}11757 \\
1734 \\
353 \\
11757 \\
11757 \\
353 \\
353 \\
1734\end{array}$ & $\begin{array}{c}<1: 2 \\
1: 4 \\
1: 4 \\
1: 4 \\
1: 8 \\
1: 16 \\
1: 64 \\
1: 128\end{array}$ & $\begin{array}{l}1 / 7 \\
1 / 7 \\
1 / 7 \\
0 / 7 \\
0 / 7 \\
0 / 7 \\
0 / 7 \\
0 / 7\end{array}$ & $\begin{array}{l}1: 128 \\
1: 8 \\
1: 128 \\
1: 16 \\
1: 16 \\
1: 32 \\
1: 32 \\
1: 128\end{array}$ & $\begin{array}{l}0 \\
0 \\
0 \\
0 \\
0 \\
0 \\
0 \\
0\end{array}$ \\
\hline Totals & & & $3 / 56(5 \%)$ & $3 / 8 \underset{\text { rises }}{\geq 4 \text {-fold }}$ & $0 / 8$ \\
\hline \multicolumn{6}{|c|}{ Simultaneous primary challenge } \\
\hline $\begin{array}{l}11 \\
10 \\
15 \\
16 \\
13 \\
14 \\
12 \\
17\end{array}$ & $\begin{array}{r}353 \\
353 \\
1734 \\
1734 \\
11757 \\
11757 \\
353 \\
1734\end{array}$ & $\begin{array}{c}<1: 2 \\
<1: 2 \\
<1: 2 \\
<1: 2 \\
1: 2 \\
1: 4 \\
1: 32 \\
1: 128\end{array}$ & $\begin{array}{l}4 / 7 \\
5 / 7 \\
3 / 7 \\
7 / 7 \\
5 / 7 \\
6 / 7 \\
5 / 7 \\
1 / 7\end{array}$ & $\begin{aligned} 1: 32 \\
1: 8 \\
1: 4 \\
1: 64 \\
1: 64 \\
1: 16 \\
1: 128 \\
>1: 512\end{aligned}$ & $\begin{array}{c}+ \\
+++ \\
++ \\
+++ \\
++ \\
++ \\
0 \\
0\end{array}$ \\
\hline Totals & & & $36 / 56(64 \%)$ & $8 / 8 \underset{\text { rises }}{\geq 4 \text {-fold }}$ & $6 / 8$ \\
\hline
\end{tabular}

Results of challenge of 25 volunteers with varying levels of naturally acquired antibody to $\mathrm{NIH}$ 1734 are described in Table V. Sixteen of these men shed virus from the nasopharynx, 6 for longer than 10 days. Paired sera from 18 of 24 demonstrated a fourfold or greater rise in antibody titer. The majority of the paired sera have been tested on more than one occasion to confirm the result, most notably those from Volunteers 26 and 45, in whom a fourfold rise in antibody titer was detected in the absence of virus shedding. Of the 7 volunteers who did not meet one of these two criteria of infection, 4 had a prechallenge antibody titer of $1: 1,024$ or greater.

Thirteen of 25 men developed an illness that, in all but one instance, was indistinguishable from the illnesses occurring in antibody-free volunteers. One volunteer with prechallenge antibody titer of $1: 128$ (No. 27) had an afebrile upper respiratory illness with nausea and vomiting on days 1 and 2 following challenge; then along with continued virus shedding, he had a recurrence of his acute symptoms on days 14 through 16 with oral temperature elevation to $37.7^{\circ} \mathrm{C}$. The typical, moderately severe illness experienced by Volunteer 57 is unexplained. Attempts to detect other etiologic agents for the latter illness, and for Volunteer 45, were unsuccessful. ${ }^{2}$

According to the data in Tables III and V from

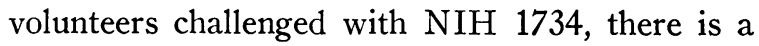
significant association of decreasing frequency and severity of illness with increasing antibody level [Greenville volunteers, Kendall's tau = .244 ; Clinical Center volunteers, tau $=-.260$; $\mathrm{p}=.03$ (combined taus)]. There was no statistically significant relationship between duration of virus shedding and increasing antibody titer when the Greenville and Clinical Center data were similarly analyzed.

Extraneous viruses were isolated from 8 volunteers during the course of these studies (Table VI). Each of these volunteers had been inoculated with NIH 1734, but nasopharyngeal wash specimens contained a virus that was not neutralized by guinea pig serum specific for NIH 1734 . These extraneous virus strains all produced en-

2 Paired sera from Volunteer 57 , as well as 45 , failed to fix complement when tested against adenovirus, parainfluenza Types 1,2 , and 3 , influenza Types $A$ and $B$, respiratory syncytial virus, and Eaton agent. These studies were performed by Mr. Horace C. Turner, Laboratory of Infectious Diseases, NIH. 
RHINOVIRUSES IN VOLUNTEERS

TABLE V

Challenge of volunteers having naturally acquired neutralizing antibody to NIH 1734

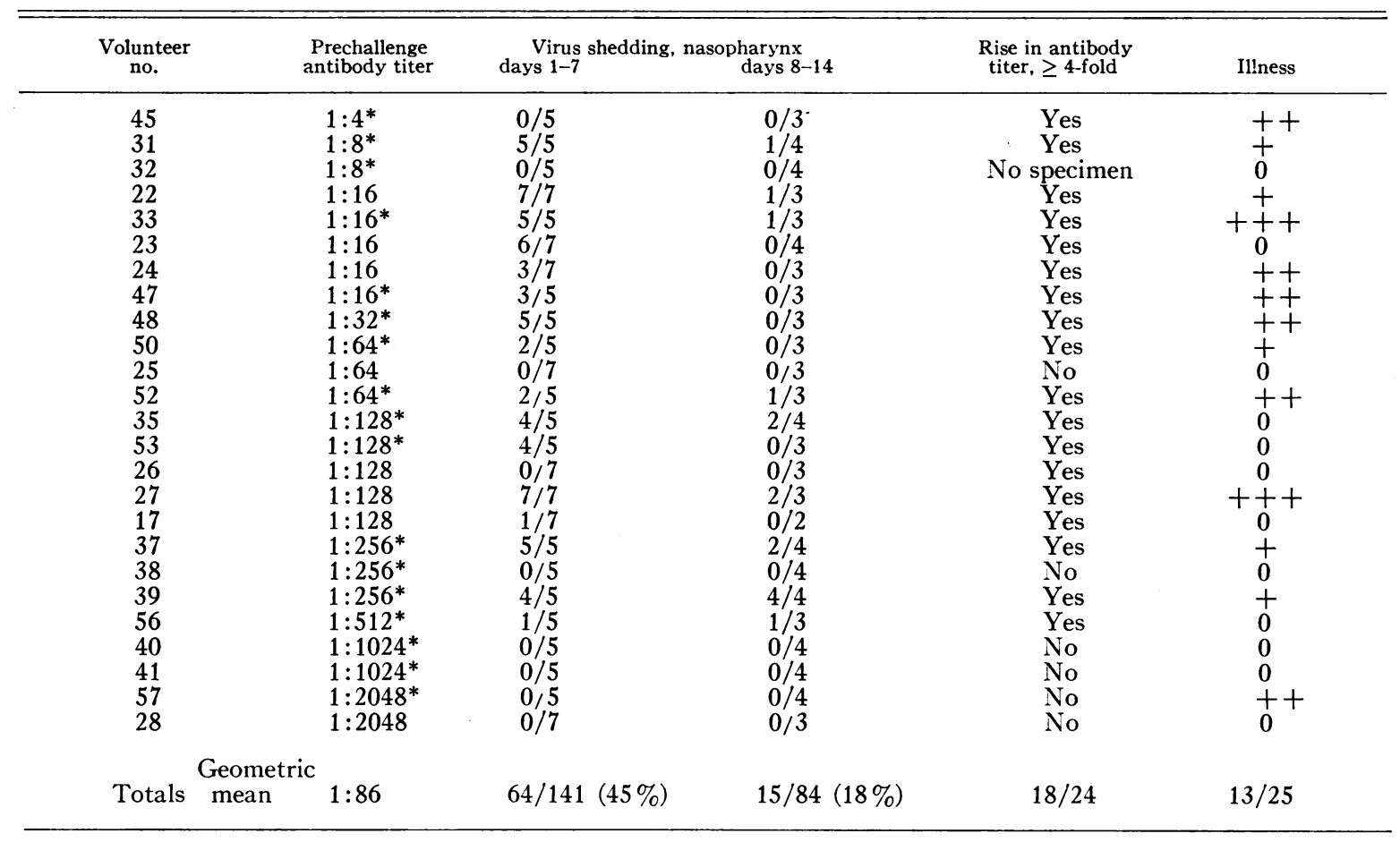

* Inoculated in Greenville, S. C., Federal Prison Camp.

terovirus CPE and were acid labile (3); they are hereafter termed "rhinoviruses." Identification of the extraneous rhinovirus from Volunteer 21, to which only 2 volunteers, 22 and 24 , were exposed, has not been completed.

The extraneous rhinovirus from 5 volunteers (Table VI) was identified as $\operatorname{HGP}$ virus $(4,5)$ by neutralization with specific guinea pig serum.
Eleven other volunteers in this group (Volunteers 42 to 57) were exposed during this outbreak of HGP infection, but in paired sera from only one, Volunteer 50, could a fourfold or greater rise in antibody titer be detected.

The extraneous rhinovirus isolated from Volunteer 34 ("No. 34 virus") did not produce $\mathrm{CPE}$ in monkey kidney cells. Specific guinea pig sera

TABLE VI

Volunteers challenged with NIH 1734 who shed an extraneous rhinovirus from the nasopharynx

\begin{tabular}{|c|c|c|c|c|c|c|}
\hline \multirow[b]{2}{*}{$\begin{array}{c}\text { Volunteer } \\
\text { no. }\end{array}$} & \multicolumn{3}{|c|}{ NIH 1734} & \multirow[b]{2}{*}{ Illness } & \multicolumn{2}{|c|}{ Extraneous virus } \\
\hline & $\begin{array}{l}\text { Prechallenge } \\
\text { antibody titer }\end{array}$ & $\begin{array}{c}\text { Virus } \\
\text { isolated }\end{array}$ & $\begin{array}{l}\text { Rise in } \\
\text { antibody } \\
\text { titer, } \\
\geq 4 \text {-fold }\end{array}$ & & $\begin{array}{l}\text { Rise in anti- } \\
\text { body titer, } \\
\geq 4 \text {-fold }\end{array}$ & Identity \\
\hline 21 & $1: 8$ & Yes & Yes & $+^{*}$ & Not tested & See text \\
\hline 34 & $1: 32$ & No & No & 0 & No & \\
\hline 36 & $1: 128$ & Yes & Yes & + & Yes & See text \\
\hline 46 & $1: 16$ & Yes & Yes & ++ & Yes & \\
\hline 49 & $1: 32$ & Yes & Yes & + & No & \\
\hline 51 & $1: 64$ & Yes & Yes & $t+$ & Yes & HGP \\
\hline 54 & $1: 128$ & No & Yes & ++ & Yes & \\
\hline 55 & $1: 256$ & Yes & No & + & Yes & \\
\hline
\end{tabular}

* This volunteer had a minor upper respiratory illness before inoculation that persisted after inoculation. 
prepared against No. 34 virus did not neutralize any of the following rhinoviruses: NIH 1734, $353,11757,33342$, and $1059(22)$, $\operatorname{HGP}(4,5)$, or $2060(8,9)$. However, hyperimmune guinea pig serum prepared against No. 34 virus did neutralize the extraneous rhinovirus from Volunteer 36. Eleven other volunteers in this group (Volunteers 29 to 41 ) were exposed to No. 34 virus, but in none of their paired sera could a fourfold rise in antibody titer be detected (no late serum was obtained from Volunteer 32).

The illnesses observed in the volunteers listed in Table VI were similar to those in other volunteers in these studies. Because of the presence of an extraneous virus, however, illness data from these volunteers cannot be interpreted in relationship to prechallenge antibody versus NIH 1734, and their data have been omitted from Table V. Even if these men are included with the other volunteers challenged with NIH 1734, the significant relationship of decreasing illness with increasing prechallenge antibody titer is not affected.

\section{Discussion}

These studies in volunteers have shown a consistent association of challenge with NIH 353, NIH 1734, and NIH 11757, and the appearance of an illness resembling experimentally induced and natural disease caused by similar agents $(21,28)$. Illness usually began within 24 hours of inoculation, and there was considerable uniformity of the syndrome regardless of the virus strain used and the antibody status of the inoculated volunteer. The illness resembled what has classically been described as "common cold," with nasal discharge and obstruction, rapid recovery, and few sequels. A slight but significant leukocytosis due to neutrophiles occurred on the first and second days following challenge with a simultaneous slight decrease in lymphocytes. Similar changes in neutrophile counts have also been noted in this laboratory in studies with Coxsackie A-21 (29). The independent finding of a positive correlation between increasing nasal secretions and severity of illness offers confirmation of the accuracy of the clinical observations on the volunteers.

Establishing that the illnesses were related to the virus strain given was important, and such was done with the inoculum most extensively employed, NIH 1734 ; there was shown to be a sig- nificant reduction in frequency and severity of illness as the titer of naturally acquired prechallenge antibody increased $(p=.03)$. Sixteen additional volunteers with prechallenge antibody titers of $<1: 2$ or $1: 2$ have been challenged with NIH 1734 in a dose of $10^{2.8}$ TCID $_{50}$ as part of a separate study (30). They all developed colds with an average illness identical to that of the 13 antibody-free volunteers included in the present report. This enhances the confidence in the association of decreasing illness with increasing prechallenge antibody. Evidence that neither the inoculation procedure itself, nor some unrecognized agent in the NIH 1734 inoculum produced illness has been obtained by giving 6 volunteers this inoculum, which had been inactivated with specific hyperimmune guinea pig serum prepared against a strain grown in different cells. There was no illness or virus shedding in this group (30).

The superiority of the nasopharyngeal washing method over nose and pharyngeal swabs for recovery of virus in the present study confirms a similar finding with the HGP agent by Bynoe and associates (19). With specimens obtained by this method, virus was recovered from 47 of 57 volunteers. Frequent occurrence of virus shedding more than 10 days after challenge and at least 5 days after acute illness is over has not been generally appreciated, but the very rare recovery of these strains from stool or rectal swab specimens is in keeping with the experience of others (1).

Neutralizing antibody titers were determined against small doses of virus, which gave a sensitive, reproducible test. Fourfold or greater rises in titer were detected in sera from 47 of $56(84 \%)$ volunteers 3 weeks after challenge. No increases in titer occurred in sera from 9 volunteers between the third and fourth weeks, and only 3 of 8 demonstrated a further $\geq$ fourfold rise at 2 months despite intervening homologous rechallenge. Jackson and co-workers (31) have presented data to the effect that following challenge with an infectious nasal secretion containing an unknown "common cold" virus, the capacity of convalescent serum to inactivate the same or antigenically similar infectious nasal secretions continues to increase in titer for 1 year. This finding, despite differences in methodology, does not appear to be in keeping with our studies. 
The 8 volunteers who received homologous rechallenge at 1 month had relatively low titers of antibody (mean titer, 1:10) and yet exhibited substantial resistance to the second challenge. They developed no illness following reinoculation and almost no virus shedding ( $5 \%$ of specimens positive for virus in the first week). In contrast, illnesses occurred in 13 of 25 volunteers with naturally acquired antibody (mean titer, 1:86), and there was a $45 \%$ incidence of specimens positive for virus the first week following inoculation. These results suggest a mechanism of resistance in the rechallenge group other than that afforded by circulating antibody as usually measured. Of possible significance in explaining this phenomenon is the 1-month time interval between the challenges, as opposed to an estimated interval of at least 6 weeks and probably longer between natural infection and inoculation of the naturally acquired antibody group, i.e., some relatively short-lived mechanism of resistance.

A similar phenomenon, undoubtedly involving more than one virus strain, has been described by Dochez, Shibley, and Mills (32) in chimpanzees. They found that these animals rarely developed colds spontaneously or after inoculations within 3 months of a previous infection. Sabin $(33,34)$ has described a possibly related situation in the resistance to reinfection of the gastrointestinal tract, lasting more than 1 year after oral attenuated poliovirus vaccine. This resistance appears to be independent of serum antibody and is not conferred by 2 doses of parenteral Salk vaccine.

A possible mechanism of local resistance to reinfection suggested by Stuart-Harris and Francis (35) may have relevance to the present results. They observed in ferrets, following challenge with influenza, a change from the normal columnar epithelium of the respiratory tract to a transitional reparative form resistant even to chemical injury. The resistance lasted 3 to 4 weeks. Another mechanism of local resistance to be considered is an effect of interferon. Resistance to rechallenge with rhinoviruses was present 1 month after first challenge and for an average period of 13 days after cessation of virus shedding. This would require the local persistence of interferon in the absence of eviclent viral multiplication for a period longer than has been experimentally recorded (36). On this basis it seems unlikely that inter- feron is the responsible factor in resistance to rechallenge.

The appearance of antibody in the nasal secretions in response to infection is thought to be important in reduction of virus spreading and prevention of illness $(20,37)$. However, in volunteers with naturally acquired antibody, there was relatively poor protection against illness and frequently prolonged virus shedding. This suggests that specific antibody in the nasal secretions does not account for the potent protection observed on rechallenge. Thus, resistance to reinfection with rhinoviruses not dependent on circulating neutralizing antibody as usually measured has not been satisfactorily explained and remains an important subject for study.

One of the difficulties of performing virological studies in human volunteers, the appearance of extraneous viruses, was amply demonstrated in these studies. It was possible, however, to prevent these events from significant interference with interpretation of the results. Dual infection with two rhinoviruses was detected in at least 6 volunteers $(21,36,46,49,51$, and 55 , Table VI). Assuming that the volunteers were not exposed to the two infecting rhinoviruses simultaneously, then there was limited resistance to superinfection early in the course, as compared to the potent protection observed on homologous rechallenge at 1 month. If a nonspecific mechanism of resistance is involved, then it is apparently not induced in the first few hours or days of the initial infection.

The rare occurrence of heterologous antibody responses in the present volunteers is evidence for the antigenic distinctiveness of the strains studied, as had been previously demonstrated in animals by Johnson and Rosen (22). With the apparent multiplicity of serologically distinct strains of rhinovirus (6) and the relatively poor protection afforded by specific antibody in these studies, control of the common cold by means of parenteral vaccines will apparently be a formidable task.

\section{Summary}

Inoculation of adult male volunteers with three strains of rhinovirus, NIH353, 1734, and 11757, was followed by a high frequency of common colds. The illnesses usually began the day after inoculation and lasted 2 to 3 days. Rhinorrhea 
and a slight but significant neutrophilic leukocytosis with a drop in lymphocytes accompanied the acute illness.

Shedding of virus was detected in nasopharyngeal wash specimens from 47 to 57 volunteers, and persisted for a period of from 1 to 2 weeks in most cases. Fourfold or greater rises in neutralizing antibody titer were detected in $84 \%$ of the volunteers by using low doses of virus in a sensitive, reproducible test.

Evidence for the rhinovirus etiology of the observed illnesses was the significant correlation of decreasing frequency and severity of illness with increasing titers of naturally acquired, prechallenge neutralizing antibody versus NIH 1734 . Antibody protection was limited, however, as demonstrated by several illnesses and frequent virus shedding in subjects with antibody before challenge. In contrast, volunteers homologously rechallenged with the three agents at 1 month, when induced antibody titers were relatively low, exhibited complete resistance to illness and almost complete absence of virus shedding. Evidence suggests that this resistance, apparently independent of serum antibody, is of brief duration; its mechanism remains obscure.

\section{Acknowledgments}

Gratitude is expressed to the following, who assisted materially in the program: Mr. James Bennett, Director, and Dr. Charles E. Smith, Chief Medical Officer, Bureau of Prisons, U. S. Department of Justice; Superintendent Joseph Thomas, Assistant Superintendent Stuart Reeves, and Mr. Larry Grossman, Federal Prison Camp, Greenville, S. C. ; Dr. Clifton K. Himmelsbach, Associate Director, and Mr. Franklyn Gray, Assistant Supervisor, Normal Volunteer Program, Clinical Center, National Institutes of Health. Mrs. Judith Rourke assisted in the technical work. Dr. David Alling performed the statistical analyses. The volunteers are commended for their excellent cooperation.

\section{References}

1. Andrewes, C. H. The taxonomic position of common cold viruses and some others. Yale J. Biol. Med. 1961, 34, 200.

2. International Enterovirus Study Group. Picornavirus Group. Virology 1963, 19, 114.

3. Tyrrell, D. A. J., and R. M. Chanock. Rhinoviruses: A description. Science 1963, 141, 152.

4. Tyrrell, D. A. J., M. L. Bynoe, G. Hitchcock, H. G. Pereira, and C. H. Andrewes. Some virus iso- lations from common colds. I. Experiments employing human volunteers. Lancet 1960, 1, 235.

5. Tyrrell, D. A. J., and R. Parsons. Some virus isolations from common colds: III. Cytopathic effects in tissue cultures. Lancet 1960, 1, 239.

6. Ketler, A., V. V. Hamparian, and M. R. Hilleman. Characterization and classification of ECHO-28rhinovirus-coryzavirus agents. Proc. Soc. exp. Biol. (N. Y.) 1962, 110, 821.

7. Price, W. H. The isolation of a new virus associated with respiratory clinical disease in humans. Proc. nat. Acad. Sci. (Wash.) 1956, 42, 892.

8. Pelon, W., W. J. Mogabgab, I. A. Phillips, and W. E. Pierce. A cytopathic agent isolated from Naval recruits with mild respiratory illnesses. Proc. Soc. exp. Biol. (N. Y.) 1957, 94, 262.

9. Pelon, W. Classification of the "2060" virus as ECHO 28 and further study of its properties. Amer. J. Hyg. 1961, 73, 36.

10. Pelon, W., and W. J. Mogabgab. Further studies on the 2060 virus. Bact. Proc. 1958, 83.

11. Hobson, D., and G. C. Schild. Virological studies in natural common colds in Sheffield in 1960. Brit. med. J. 1960, 2, 1414.

12. Tyrrell, D. A. J., and M. L. Bynoe. Some further virus isolations from common colds. Brit. med. J. 1961, 1, 393.

13. Hamre, D., and J. J. Procknow. Viruses isolated from natural common colds in the U. S. A. Brit. med. J. 1961, 2, 1382.

14. Mogabgab, W. J. Additional respirovirus type related to G. L. 2060 (ECHO-28) virus from military personnel, 1959. Amer. J. Hyg. 1962, 76, 160.

15. Hilleman, M. R., V. V. Hamparian, A. Ketler, C. M. Reilly, L. McClelland, D. Cornfeld, and J. Stokes, Jr. Acute respiratory illnesses among children and adults: field study of contemporary importance of several viruses and appraisal of the literature. J. Amer. med. Ass. 1962, 180, 445.

16. Johnson, K. M., H. H. Bloom, R. M. Chanock, M. A. Mufson, and V. Knight. Respiratory diseases of viral etiology: VI. The newer enteroviruses. Amer. J. publ. Hlth 1962, 52, 933.

17. Hilleman, M. R. Respiratory viruses and respiratory virus vaccines. Amer. Rev. resp. Dis. 1963, 87, 165.

18. Tyrrell, D. A. J., and M. L. Bynoe. Inoculation of volunteers with $J$. H. strain of new respiratory virus. Lancet 1958, 2, 931.

19. Bynoe, M. L., J. Horner, G. C. Schild, D. Hobson, A. Kipps, and D. A. J. Tyrrell. Inoculation of human volunteers with a strain of virus isolated from a common cold. Lancet 1961, 1, 1194.

20. Tyrrell, D. A. J. Further experiments on viruses isolated from common colds (rhinoviruses) in Perspectives in Virology III, M. Pollard, Ed. New York, Harper and Row, 1963, p. 238.

21. Jackson, G. G., H. F. Dowling, and W. J. Mogabgab. Infectivity and interrelationships of 2060 and $\mathrm{JH}$ 
viruses in volunteers. J. Lab. clin. Med. 1960, 55, 331.

22. Johnson, K. M., and L. Rosen. Characteristics of five newly recognized enteroviruses recovered from the human oropharynx. Amer. J. Hyg. 1963, 77, 15.

23. Hayflick, L., and P. S. Moorhead. The serial cultivation of human diploid cell strains. Exp. Cell Res. 1962, 25, 585.

24. Couch, R. B., R. M. Chanock, T. R. Cate, D. J. Lang, and $\mathrm{V}$. Knight. Immunization with types 4 and 7 adenovirus by selective infection of the intestinal tract. Amer. Rev. resp. Dis. 1963, 88: 3 (suppl.), 394.

25. Reed, L. J., and H. Muench. A simple method of estimating fifty per cent endpoints. Amer. J. Hyg. 1933, 27, 493.

26. Kendall, M. G. Rank Correlation Methods, 2nd ed. London, Charles Griffin, 1955.

27. Dixon, W. J., and F. J. Massey. Introduction to Statistical Analysis, 2nd ed. New York, McGrawHill, 1957, p. 124.

28. Reilly, C. M., S. M. Hoch, J. Stokes, Jr., L. McClelland, V. V. Hamparian, A. Ketler, and M. R. Hilleman. Clinical and laboratory findings in cases of respiratory illness caused by coryzaviruses. Ann. intern. Med. 1962, 57, 515.

29. Spickard, A., H. Evans, V. Knight, and K. Johnson. Acute respiratory disease in normal volunteers associated with Coxsackie A-21 viral infection. III. Response to nasopharyngeal and enteric inoculation. J. clin. Invest. 1963, 42, 840.
30. Couch, R. B., T. R. Cate, W. F. Fleet, and V. Knight. To be published.

31. Jackson, G. G., H. F. Dowling, L. W. Akers, R. L. Muldoon, A. V. Duke, and G. C. Johnson. Immunity to the common cold from protective serum antibody; time of appearance, persistence, and relation to infection. New Engl. J. Med. 1962, 266, 791.

32. Dochez, A. R., G. S. Shibley, and K. C. Mills. Studies in the common cold. IV. Experimental transmission of the common cold to anthropoid apes and human beings by means of a filtrable agent. J. exp. Med. 1930, 52, 701.

33. Sabin, A. B. Present status of attenuated live virus poliomyelitis vaccine. Bull. N. Y. Acad. Med. 1957, 33, 17.

34. Sabin, A. B. Status of field trials with an orally administered live attenuated poliovirus vaccine. J. Amer. med. Ass. 1959, 171, 863.

35. Stuart-Harris, C. H., and T. Francis, Jr. Studies on the nasal histology of epidemic influenza virus infection in the ferret. II. The resistance of regenerating respiratory epithelium to reinfection and to physicochemical injury. J. exp. Med. 1938, $68,803$.

36. Ho, M. Interferons. New Engl. J. Med. 1962, 266, 1313.

37. Anderson, T. O., L. J. M. Riff, and G. G. Jackson. Immunoelectrophoresis of nasal secretions collected during a common cold: Observations which suggest a mechanism of seroimmunity in viral respiratory infections. J. Immunol. 1962, 89, 691. 